\title{
MIGRASI KE SCILAB UNTUK VISUALISASI SERTA PENYELESAIAN MODEL MATEMATIS
}

\author{
Setia Budi Sasongko \\ Jurusan Teknik Kimia Fakultas Teknik UNDIP Semarang \\ Jl. Prof. Soedarto, SH, Tembalang, Semarang 50239, Telp.(024)7460058 \\ E-mail: budisas@undip.ac.id
}

\begin{abstract}
Abstrak
Perangkat lunak merupakan salah satu komponen yang mutlak diperlukan dalam simulasi komputer. Permasalahan harga menjadi salah satu kendala dalam pengembangan sistem tersebut. Akan tetapi problema tersebut dapat diatasi dengan menggunakan Scilab sebagai "Open Source Software". Scilab merupakan perangkat lunak berbasis matrik dalam menyelesaian permasalahan matematis dan visualisasi hasilnya.Penyusunan program didasarkan pada model matematis untuk bioreaktor. Validasi hasil dari Scilab dilakukan melalui komparasi hasil visualisasi dengan perangkat lunak Polymath 5 versi pendidikan. Hasil yang diperoleh dari Scilab tidak menunjukkan perbedaan yang signifikan dengan hasil yang diperoleh dengan Polymath 5. Berdasarkan hasil tersebut, perlu dikembangkan lebih lanjut simulasi komputasi dengan menggunakan Scilab.
\end{abstract}

Kata kunci : bioreaktor, OSS (Open Source Software), Polymath, Scilab, simulasi komputer

\begin{abstract}
Software is required for the computer simulation, but relatively-high price of the software hinders the development of simulation program. The best way to overcome the obstacle is by using Scilab software, as it is one of the software provided by Open Source Software (OSS). Scilab is based on the matrices in solving mathematical problem and visualizing the results. A computer program based on a mathematical model for bioreactor has been composed using by Scilab. The results of the program are then compared to those obtained by using Polymath 5 education version. The results obtained from Scilab do not show significant different from those obtained by using Polymath 5.
\end{abstract}

Keywords : bioreactor, OSS (Open Source Software), Polymath, Scilab, computer simulation

\section{PENDAHULUAN}

Simulasi sebagai suatu aktivitas menirukan kejadian atau keadaan yang sesungguhnya, dengan demikian pengguna akan mendapatkan gambaran, fenomena atau kinerja dari sistem atau proses yang dikaji dengan menggunakan alat bantu simulator. Ada berbagai macam bentuk simulator, akan tetapi dalam tulisan ini digunakan simulator dengan bantuan (berbasis) komputer (selanjutnya disebut dengan simulasi komputer) sebagai alat bantu analisis obyek kajian. Dalam industri, simulasi komputer dapat juga digunakan sebagai training operator sehingga dapat meningkatkan kemampuannya dalam mengoperasikan sistem proses ataupun satuan operasi.

Dalam simulasi komputer, selain diperlukan perangkat keras, yang tidak kalah pentingnya adalah perangkat lunak. Saat ini yang menjadi kendala dalam perangkat lunak adalah masalah harga yang relatif mahal. Akan tetapi dengan berjalannya waktu telah dikembangkan perangkat lunak yang dapat digunakan secara umum (gratis). Salah satu perangkat lunak tersebut adalah Scilab yang dapat diperoleh melalui alamat www.scilab.org. Perangkat lunak ini dikembangkan oleh INRIA dan ENPC, Perancis yang berawal untuk aplikasi sistem pengendalian dan pemrosesan sinyal. Pengembangan serta pemeliharaannya dilakukan oleh Konsorsium Scilab (Arief S, www.ilmukomputer.com). Scilab tersedia dalam berbagai sistem operasi seperti Windows, Linux, Unix, dan Mac OS/X. Perangkat lunak ini hampir mirip dengan perangkat lunak Matlab yaitu penyelesaian sistem persamaan berbasis matrik. Hanya saja perangkat lunak ini masih relatif baru dibandingkan dengan program pendahulunya. Oleh karenanya masih banyak pemrogram yang belum mengetahui tentang penggunaan dan kelebihan dari program ini. 
Tulisan ini bertujan menyusun program Scilab untuk simulasi komputer bioreaktor, dengan harapan akan menambah gagasan dalam mengembangkan dan penyusunan program Scilab. Program disusun dalam bentuk sub rutin (fungsi) dengan demikian dapat digunakan secara umum.

\section{Fundamental}

Tahap pertama dalam membangun simulator ini adalah menyusun model matematis. Model dapat disusun dari persamaan empiris berdasarkan data percobaan atau data lapangan ataupun model yang disusun berdasarkan pendekatan dari sekumpulan persamaan yang saling berkaitan dalam bentuk sebabakibat (causal model). Penyusunan model yang terakhir disebut juga dengan model deterministik atau white-box model.

Bioreaktor banyak digunakan untuk memproduksi produk antara maupun produk akhir pada industri seperti farmasi, makanan ataupun minuman. Penyusunan model bioreaktor berdasarkan konservasi massa seperti pada model reaktor kimia yang merupakan kompilasi dari Fogler (1999), Bequette (1998), dan James (1978). Simplifikasi masalah pada model matematis hanya ada tiga komponen yaitu biomassa, produk, dan substrat pada reaktor. Biomassa merupakan sel mikroorganisme yang akan mengkonsumsi substrat. Penyusunan stoikiometri dari pertumbuhan sel (mikro organisme) cukup kompleks dan bervariasi terhadap jenis mikro organisme-nutrien dan juga kondisi lingkungannya. Oleh karenanya dalam penyusunan persamaan stoikiometri diambil asumsi hanya terdiri dari satu sel dan satu medium nutrien. Apabila $C$ sebagai notasi biomassa (Cell) dan $S$ sebagai substrat, maka secara umum dapat dituliskan:

Biomas (Cell)+Substrat $\rightarrow$ Sel tumbuh+produk

$$
S \stackrel{\operatorname{biomas}(\mathrm{Sel})}{\longrightarrow} Y_{\mathrm{C} / \mathrm{S}} \mathrm{C}+Y_{P / S} P
$$

Produk dapat berupa $\mathrm{CO}_{2}$, air, protein, dan produk spesifik yang lain. Pada persamaan (1b), $Y$ merupakan koefisien stoikiometri, yield pembentukan sel $\left(Y_{C / S}\right)$ atau produk $\left(Y_{P / S}\right)$ terhadap substrat $(S)$. Jumlah subtrat $(S)$ yang dikonsumsi biomassa digunakan untuk pertumbuhan sel $(C)$, membentuk produk dan untuk perawatan/ pertahanan (maintenance) sel. Dalam satuan massa komponen tiap satuan waktu dan volume, kecepatan berkurangnya substrat dapat dituliskan sebagai:

$$
-r_{S}=Y_{S / C} r_{t u m}+Y_{S / P} r_{P}+m \cdot C_{C}
$$

Kecepatan pertumbuhan dari sel $\left(r_{\text {tum }}\right)$ ekivalen dengan persamaan kecepatan reaksi orde satu.

$$
r_{\text {tum }}=\mu . C_{C}
$$

Dimana $\mu$ atau kecepatan pertumbuhan spesifik dari sel tidak konstan. Menurut Monod, $\mu$ merupakan fungsi hiperbola dengan bentuk serupa dengan persamaan
Michaelis-Menten yang digunakan untuk mendeskripsikan interaksi antara enzim-substrat.

$$
\mu=\mu_{\max }\left[\frac{C_{S}}{K_{S}+C_{S}}\right]
$$

Persamaan (4) tersebut kurang valid untuk kondisi tertentu, karena pada sistem tertentu terjadi proses yang menghambat pertumbuhan. Persamaan dengan adanya fungsi adanya penghambat (inhibitor) pertumbuhan dikemukakan oleh Andrew (James, 1978) dengan adanya konstanta inhibisi, $K_{i}$.

$$
\mu=\mu_{\max }\left[\frac{1}{1+\frac{K_{S}}{C_{S}}+\frac{C_{S}}{K_{i}}}\right]
$$

Proses penghambatan pertumbuhan sel dapat disebabkan oleh pembentukan produk seperti pada fermentasi glukosa membentuk etanol yang bertindak sebagai penghambat (Fogler, 1999). Dengan adanya proses penghambatan pada sistem maka persamaan (4) ditambah dengan $k_{\text {obs }}$ yang merupakan fungsi konsentrasi produk, sebagaimana yang ditunjukkan pada persamaan (6a) dan (6b).

$$
\mu=k_{\text {obs }} \cdot \mu_{\max }\left[\frac{C_{S}}{K_{S}+C_{S}}\right]
$$

dengan

$$
k_{\text {obs }}=\left(1-\frac{C_{P}}{C_{P}^{*}}\right)^{n}
$$

Dimana:

$$
\begin{aligned}
C_{P} *= & \text { Konsentrasi produk yang akan menghambat } \\
& \text { metabolisme }\left(\mathrm{g} / \mathrm{dm}^{3}\right) \\
\mathrm{n} \quad= & \text { konstanta empiris }
\end{aligned}
$$

Pada fermentasi glukosa menjadi etanol parameter inhibisi adalah $n=0.5$ dan $C_{p} *=93 \mathrm{~g} / \mathrm{dm}^{3}$ (Fogler, 1999).

Konsumsi dari substrat digunakan untuk memproduksi sel baru, akan tetapi sebagian dari substrat digunakan untuk mempertahankan aktivitas rutin dari sel. Keadaan ini, dalam persamaan kecepatan pertahanan dinyatakan dengan adanya koefisien $m$ yaitu (jumlah substrat yang dikonsumsi untuk pertahanan / jumlah sel•waktu). Dalam bentuk persamaan kecepatan pertahanan adalah $r_{s m}=m . C_{c}$.

Jumlah atau berat sel (C) juga akan menurun disebabkan kematian yang bersifat alami ataupun karena adanya racun (toxic) terhadap sel tersebut. Kecepatan kematian dari sel dinyatakan dalam bentuk persamaan (7).

$$
r_{\text {mat }}=\left(k_{\text {mat }}+k_{\text {rac. }} C_{\text {rac }}\right) \cdot C_{C}
$$

Nilai $k_{\text {mat }}$ berkisar antara 0.1 jam $^{-1}$ sampai di bawah $0.0005 \mathrm{jam}^{-1}$. Sedangkan nilai $k_{\text {rac }}$ tergantung pada sifat racun terhadap sel.

Yang perlu mendapat perhatian adalah dalam satu siklus, mikroorganisme mengalami 4 fase perkembangan, yaitu pertama fase perlambatan (lag 
phase), kedua fase eksponensial, ketiga fase stasioner dan terakhir fase kematian.

Untuk mengetahui karakteristik jumlah atau konsentrasi dari sel $(C)$, substrat $(S)$ dan produk $(P)$ maka perlu disusun persamaan neraca massa pada sistem kontinyu (CSTR) pada volume tetap, dengan persamaan neraca massa secara umum yaitu

[Kec. Akumulasi $]=[$ kec. masuk $]-[$ kec. Keluar $]+$

$$
\text { [kec. Pertumbuhan] }
$$

Neraca massa untuk sel (mikro organisme):

$$
V \frac{d C_{C}}{d t}=F_{\text {in }} C_{C_{-} \text {in }}-F_{\text {out }} C_{C}+\left(r_{\text {tum }}-r_{\text {mat }}\right) V
$$

Sedangkan neraca massa untuk substrat:

$$
V \frac{d C_{S}}{d t}=F_{\text {in }} C_{S_{-} \text {in }}-F_{\text {out }} C_{S}+r_{S} V
$$

Pada umumnya, konsentrasi mikro organisme masuk $C_{\text {S-in }}=0$.

Pada sistem batch, persamaan (8) dan (9) berubah menjadi:

O Sel:

$$
\frac{d C_{c}}{d t}=r_{\text {tum }}-r_{\text {mat }}
$$

Substrat:

Berkurangnya substrat dapat dibagi menjadi dua bagian:

- Pada fase pertumbuhan/eksponensial (fase ke 2)

$$
\frac{d C_{S}}{d t}=r_{S}=Y_{S / C}\left(-r_{\text {tum }}\right)-m \cdot C_{C}
$$

- $\quad$ Fase stasioner (fase ke3)

Pada fase ini, sel tidak mengalami pertumbuhan, substrat digunakan perawatan dan pembentukan produk.

$$
\frac{d C_{S}}{d t}=-m \cdot C_{C}+Y_{S / P} \cdot\left(-r_{P}\right)
$$

Produk:

$$
\frac{d C_{P}}{d t}=r_{P}=Y_{P / S}\left(-r_{S}\right)
$$

\section{METODE PENELITIAN}

Gambar 1 merupakan kerangka pikir untuk mengetahui karakteristik dari substrat, mikro organisme, dan produk pada bioreaktor pada sistem batch.

Parameter atau konstanta menggunakan data dari Fogler (1999). Hasil perhitungan dengan Scilab dilakukan komparasi hasil dengan menggunakan perangkat lunak Polymath 5 versi pendidikan. Perangkat lunak tersebut merupakan bagian dari CDROM CRE_99 Fogler (1999).

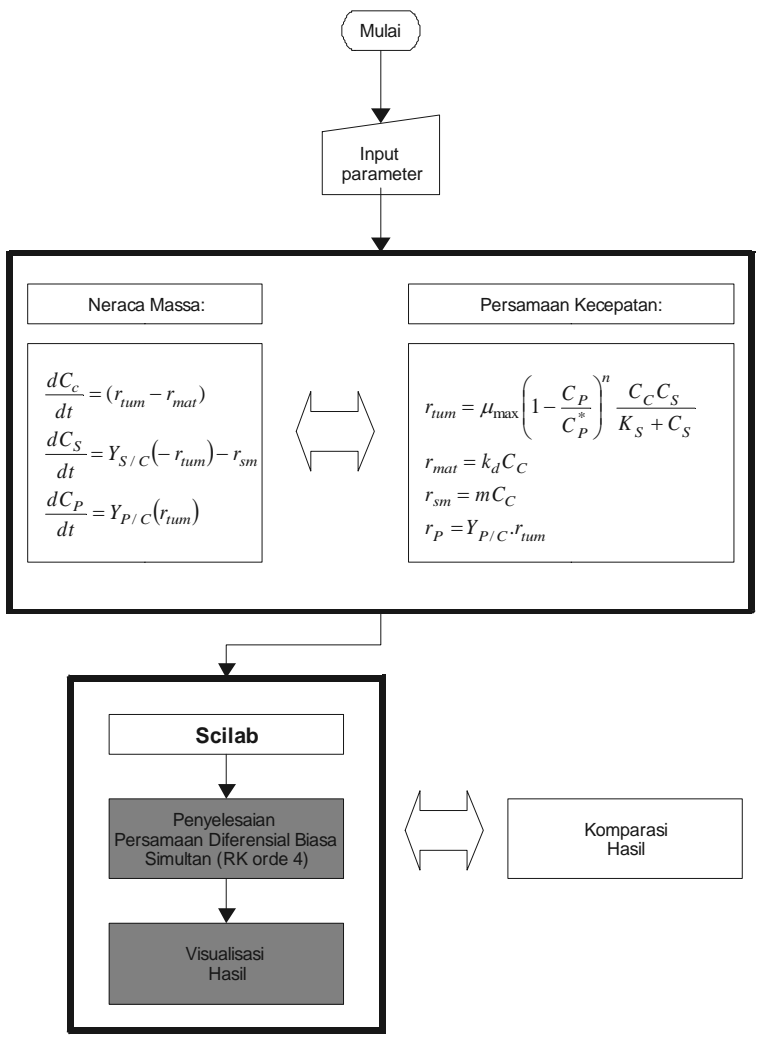

Gambar 1. Kerangka pikir

\section{HASIL DAN PEMBAHASAN}

Sub Rutin Persamaan Diferensial Biasa (PDB)

Sebagaimana pada perangkat lunak Matlab, Scilab juga menyediakan sub rutin untuk menyelesaikan persamaan diferensial biasa berdasarkan kondisi awal dengan bentuk perintah

\section{$y=\operatorname{ode}(y \odot, t \odot, t, f)$}

\section{Dimana:}

$$
\begin{array}{rlrl}
\mathrm{y} \odot, \mathrm{t} \odot= & \text { kondisi awal dari } \mathrm{t} \text { (variabel bebas) } \\
& \text { dan } \mathrm{y} \text { (variabel tak bebas) } \\
\mathrm{t} & = & \text { waktu dimana penyelesaian dihitung } \\
\mathrm{f} & = & \text { fungsi dari persamaan }
\end{array}
$$

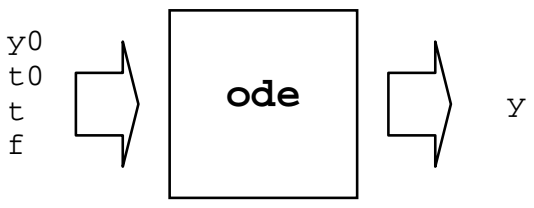

Arti dari sub rutin tersebut sebagai masukkan dari fungsi ode adalah $\mathrm{y} 0, \mathrm{t} 0, \mathrm{t}, \mathrm{f}$, sedangkan hasil keluarannya adalah y. Perintah tersebut digunakan pada program 01a dan program 01b yang merupakan penyelesaian dan visualisasi hasil (y) dari model matematis pada sistem bioreaktor secara batch, dengan hasil visualisasinya dapat dilihat pada gambar 2 dan gambar 3 sebagai gabungan dari konsentrasi sel, substrat, dan produk sebagai fungsi waktu. 
Program 01a:

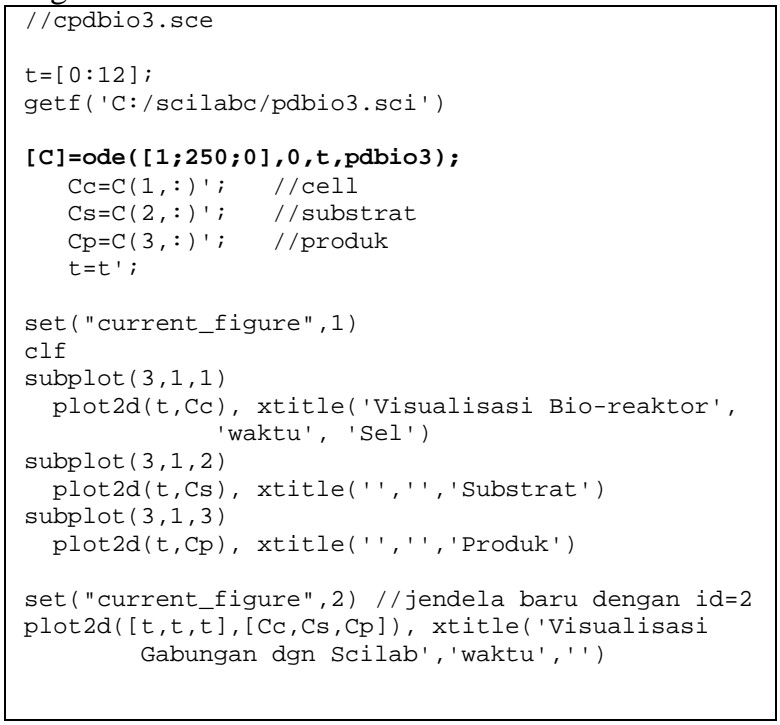

Program 01b:
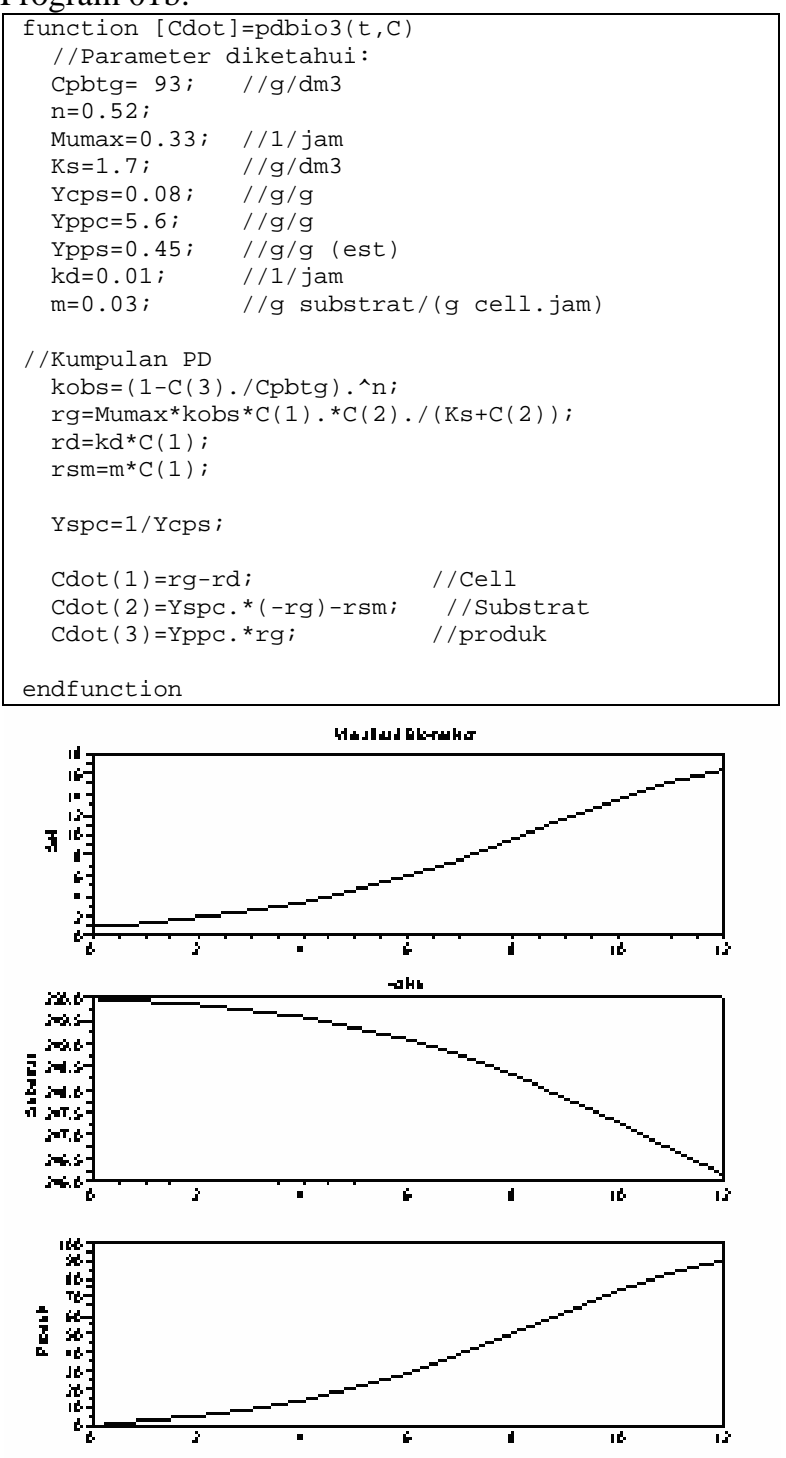

Gambar 2. Visualisasi hasil pada bioreaktor dengan Scilab

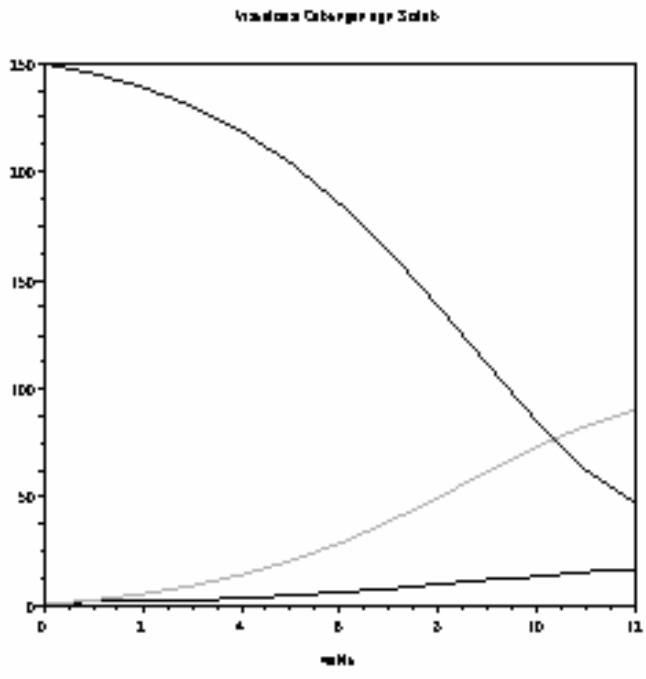

Gambar 3. Visualisasi gabungan dari konsentrasi sel, substrat dan produk sebagai fungsi waktu.

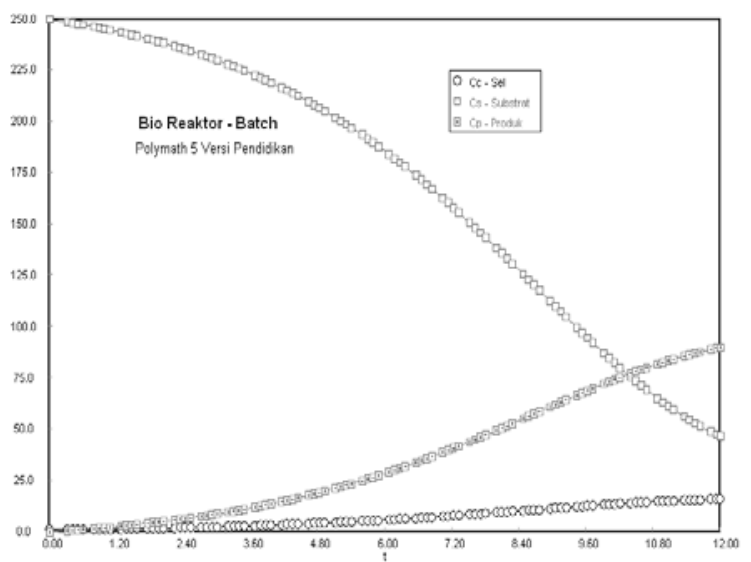

Gambar 4. Visualiasasi hasil dengan menggunakan Polymath 5 versi pendidikan (Fogler, 1999).

Kesahihan (validitas) dari penyelesaian dengan menggunakan Scilab dapat dilihat dengan membandingkan hasil visualisasi antara gambar 3 (sebagai produk Scilab) dengan gambar 4 yang merupakan produk dari Polymath. Kedua gambar menunjukkan tren (kecenderungan) yang sama.

Susunan program serta parameter masukkan dengan menggunakan Polymath dapat dilihat pada program 02P.

\section{Sub Rutin PDB Dengan Masukan Parameter}

Permasalahan yang muncul dari penggunaan sub rutin siap pakai pada Scilab [ode] adalah parameter atau konstanta harus masuk pada sub rutin persamaan diferensial sebagaimana yang ditunjukkan pada program 1b. Keadaan ini kurang menguntungkan, karena program tersebut bersifat kurang akrab pengguna (user friendly).

Untuk mengatasi hal tersebut perlu dikembangkan sub rutin dimana parameter atau konstanta dapat dimasukkan pada sub rutin tersebut. 
Program 02P.

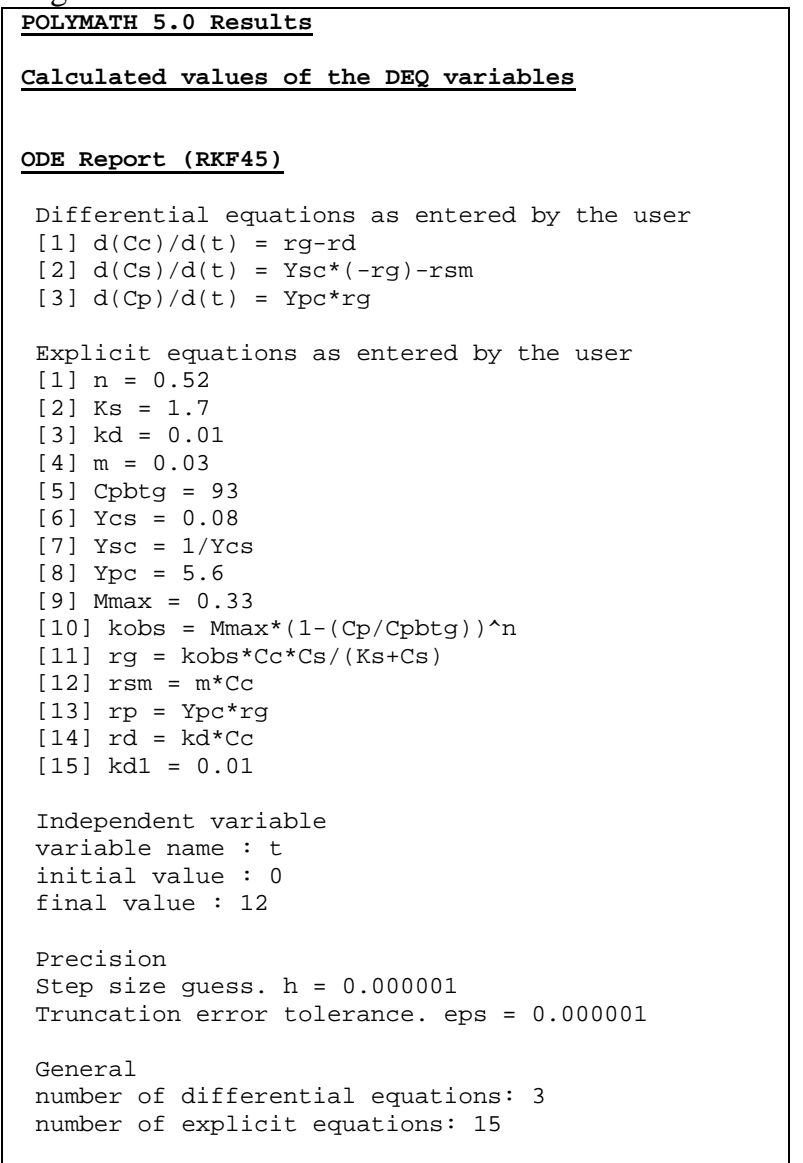

\section{Program 03a.}

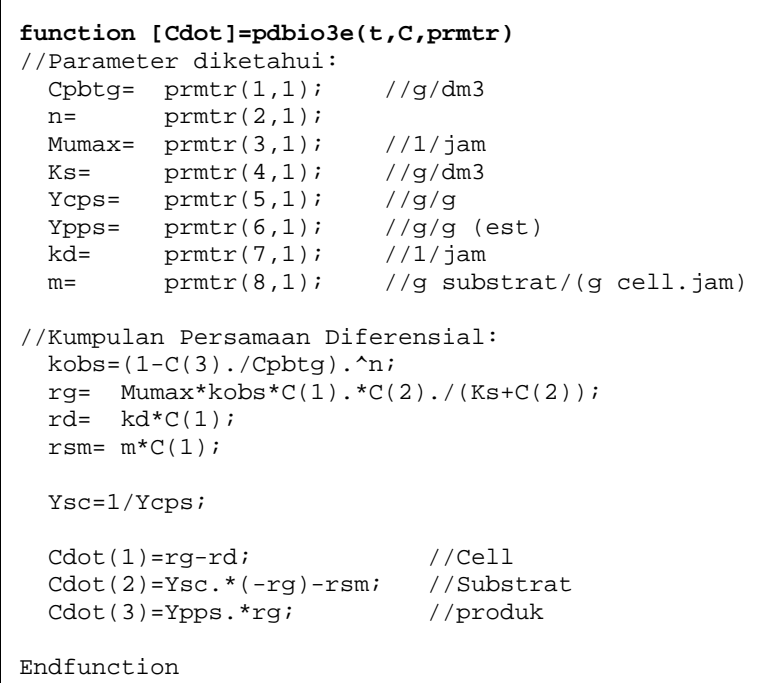

Program 03a merupakan modifikasi dari program 01b dengan menambahkan variabel dengan nama prmtr. Nilai dari parameter tersebut tidak perlu dimasukkan dalam sub rutin pdbio3e, akan tetapi nilai tersebut dapat dibaca pada sub rutin pdbio3e tanpa harus membuat variabel global. Akan tetapi dengan memasukkan unsur variabel prmtr pada program 03a, maka harus dikembangkan penyelesaian persamaan diferensial dengan memasukkan unsur variabel dari luar.

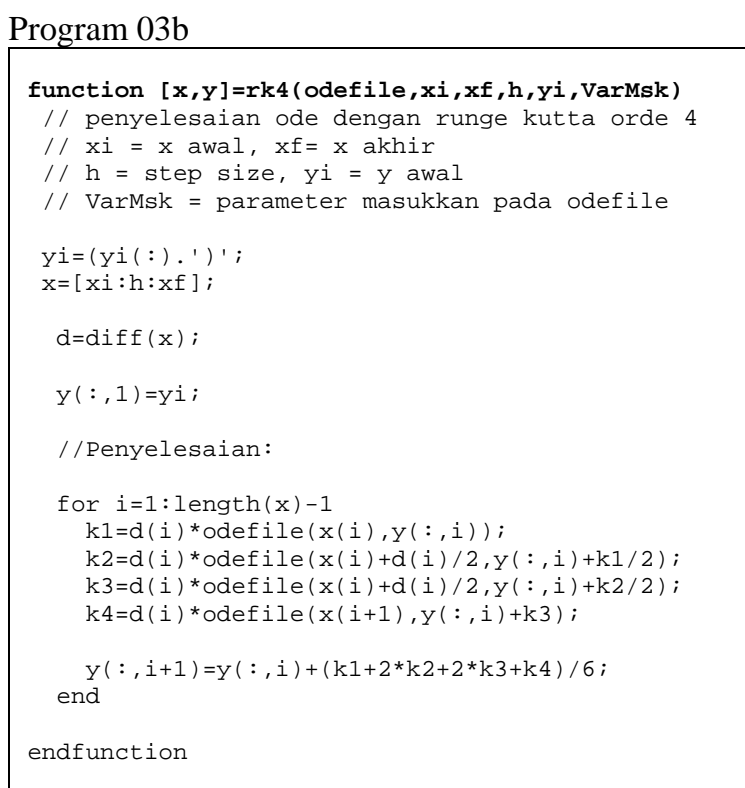

Program 03b merupakan program penyelesaian persamaan diferensial biasa dengan metoda Runge-Kutta orde 4 dan menambahkan variabel masukan dengan nama VarMsk. Penyelesaian persamaan diferensial biasa dengan metoda Runge-Kutta order 4 menunjukkan hasil yang baik apabila digunakan step size (h) yang relatif kecil (Constantinides, and Mostoufi, 2000), dalam hal ini digunakan nilai 0,01.

Program 03c.

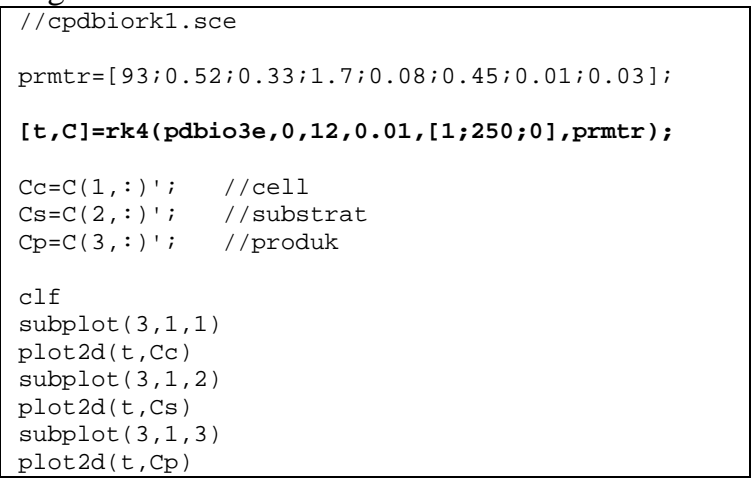

Program 03c dapat dikembangkan sebagai sub rutin untuk reaktor biokimia. Dengan demikian dapat digunakan sebagai salah satu modul reaktor proses batch.

\section{KESIMPULAN}

Simulasi komputer sebagai salah satu bagian untuk menganalisis karakteristik dari suatu sistem proses yang dapat digunakan sebagai perancangan dan pengendalian dari sistem tersebut. Salah satu perlengkapan yang diperlukan dan simulasi komputer tersebut adalah perangkat lunak yang handal, stabil, 
dan terjangkau dari segi harga. Scilab merupakan salah satu pilihan perangkat lunak yang memenuhi kriteria tersebut. Penyusunan program dengan menggunakan Scilab menunjukkan hasil yang bagus berdasarkan komparasi visalisasi dengan perangkat lunak Polymath 5.0 versi pendidikan. Penyusunan program cukup singkat, baik berdasarkan sub rutin yang telah tersedia maupun sub rutin hasil pengembangan perangkat lunak ini karena berbasis matrik sebagaimana perangkat lunak Matlab.

\section{UCAPAN TERIMA KASIH}

Pada kesempatan ini, penulis mengucapkan terima kasih pada konsorsium Scilab yang telah mengijinkan penggunaan perangkat lunak Scilab.

\section{DAFTAR NOTASI}

$r_{\text {tum }}=$ kecepatan pertumbuhan sel (biomassa), $\mathrm{g} / \mathrm{dm}^{3} \mathrm{det}$

$r_{P} \quad=$ kecepatan pembentukan produk

$-r_{S}=$ kecepatan berkurangnya substrat

$r_{\text {mat }}=$ kecepatan kematian dari sel

$Y \quad=$ yield koefisien

$\mu \quad=$ kecepatan pertumbuhan spesifik

$C_{i}=$ konsentrasi dari $i(\mathrm{C}=$ sel; $\mathrm{S}=$ substrat dan $\mathrm{P}=$ produk)

\section{DAFTAR PUSTAKA}

Arief, S. "Beberapa Freeware Pengganti MATLAB" (http://www.ilmukomputer.com)
Arief, S. "Sekilas tentang Scilab" ( http:// ilmukomputer.com/2008/04/09/sekilas-tentangscilab)

Bequette, B.W., (1998), “Process Dynamics, modeling, analysis and simulation”, Prentice Hall PTR, NJ.

Chandler, G. And Roberts, S., (2002), "Introduction to Scilab”, (http://comptlsci.anu.edu.au/scilab/ primer.pdf)

Constantinides, A., and Mostoufi, N., (2000), "Numerical Methods for Chemical Engineers with MATLAB Applications”, Prentice Hall PTR, NJ.

Fogler, H. S., (1999), "Elements of Chemical Reaction Engineering”, $3^{\text {rd }}$ edition, Prentice Hall International Series, NJ.

Gomez, C., and Goursat, M., “Metanet User's Guide and Tutorial, Manual version 1.1 for Scilab 2.4”, (http://www.snv.jussieu.fr)

James, A, Editor, (1978), "Mathematical Models in Water Pollution Control”, John Wiley \& Sons Ltd.

http://www.scilab.org

Rietsch, E., (2002), “An Introduction to Scilab from a Matlab User's Point of View”, (http:/www.math.tuberlinde/ ehrhardt/scilab/doc/html/intro)

Scilab Group, “Intoduction to Scilab”, INRIA Meta2 Project/ ENPC Cergrene (http://wwwrocq.inria.fr/scilab). 